\title{
Efektivitas Pelaksanaan E-Complaint (Studi Kasus pada Pusat Informasi, Dokumentasi, dan Keluhan Universitas Brawijaya)
}

\author{
Fajar Andy Kurniawan ${ }^{a} *$ \\ ${ }^{a}$ Universitas Brawijaya, Malang, Jawa Timur, Indonesia
}

\section{INFORMASI ARTIKEL}

\section{Article history:}

Dikirim tanggal: 27 Agustus 2018

Revisi pertama tanggal: 29 Agustus 2018

Diterima tanggal: 07 Desember 2018

Tersedia online tanggal: 13 Desember 2018

Keywords: effectivity, service users, $e$ complaint

\section{ABSTRACT}

The main purpose of this research is to analyze the effectiveness of e-complaint implementation, and to find out the constraints faced in the implementation. The theory used is the theory of public service. This research was designed with qualitative descriptive method, data collected through interview, documentation and observation methods. The results of this study indicate that: first, the implementation of e-complaint UB as a whole has been running well, both in terms of input, output and productivity. Although in terms of process is still not optimal. Second, there are some obstacles faced in the implementation of ecomplaint. Which is divided into two, internal and external. Internal obstacles include: human resources, internet network, and e-complaint application maintenance costs. External constraints include: the lack of feedback from service users and the mindset of service provider and service user who do not consider the importance of e-complaint.

\section{INTISARI}

Tujuan utama dari penelitian ini adalah untuk menganalisis efektivitas pelaksanaan e-complaint, dan untuk mengetahui kendala-kendala yang dihadapi dalam implementasi. Teori yang digunakan adalah teori pelayanan publik. Penelitian ini dirancang dengan metode deskriptif kualitatif, data dikumpulkan melalui wawancara, dokumentasi dan metode observasi. Hasil penelitian ini menunjukkan bahwa: pertama, implementasi e-complaint UB secara keseluruhan sudah berjalan cukup efektif, baik dari segi input, output maupun produktivitas. Meski dari segi prosesnya masih belum optimal. Kedua, ada beberapa kendala yang dihadapi dalam penerapan $e$-complaint. Yang terbagi menjadi dua, internal dan eksternal. Hambatan internal meliputi: sumber daya manusia, jaringan internet, dan biaya pemeliharaan aplikasi $e$-complaint. Kendala eksternal meliputi: kurangnya umpan balik dari pengguna layanan dan pola pikir penyedia layanan dan pengguna layanan yang kurang mempertimbangkan pentingnya e-complaint. 


\section{Pendahuluan}

Daya saing sebuah perguruan tinggi merupakan suatu bentuk implementasi dari peningkatan kualitas sumber daya manusia, modernisasi manajemen, penguatan sistem informasi, transformasi teknologi serta pembaharuan kelembagaan. Berbagai upaya dilakukan untuk meningkatkan kualitas pelayanan dengan mengoptimalkan seluh potensi yang dimiliki, salah satunya adalah mengaplikasikan berbagai teknologi informasi dalam proses penyelenggaraan pelayanan. Secara keseluruhan peningkatan layanan mengacu kepada meningkatnya efisiensi dan kualitas pelayanan yang didukung oleh kelayakan dan keterampilan profesional dalam berbagai aspek.

Universitas Brawijaya sebagai salah satu lembaga yang memberikan pelayanan dibidang pendidikan telah berkembang pesat dalam beberapa tahun terakhir. Universitas Brawijaya memberikan layanan kepada banyak pihak, antara lain mahasiswa, masyarakat umum, civitas akademika, aparat pemeriksa internal dan eksternal serta kepada pihak ketiga. Pemberian layanan kepada berbagai pihak tersebut, tentunya harus memiliki layanan yang prima dan memuaskan. Dalam hal ini Universitas Brawijaya telah memiliki standar dalam melakukan pelayanan dan indikator atau indeks dalam mengukurnya.

Dalam melaksanakan pelayanan, meskipun telah memiliki standar pelayanan minimum yang jelas, akan tetapi masih akan dihadapkan pada ketidakpuasan sebagian pengguna layanan. Ketidakpuasan dalam bentuk keluhan dan tanggapan pengguna layanan terhadap Universitas Brawijaya tersebut adalah salah satu hal penting untuk meningkatkan mutu kinerja serta layanan sebuah Perguruan Tinggi. Oleh sebab itulah penanganan keluhan atas ketidakpuasan pengguna layanan terhadap kinerja Universitas Brawijaya perlu untuk dicermati lebih lanjut dimana keluhan dan tanggapan yang dirasakan oleh pengguna layanan semakin lama semakin berkembang dalam tataran prakteknya.

Dengan berkembangnya waktu, maka penyampaian keluhan dan saran dapat dilakukan secara elektronis. Mekanisme interaksi mutakhir diantara pemerintah dengan masyarakat dan golongan lain yang berkepentingan (stakeholder); yang melibatkan penggunaan teknologi informasi (terutama internet); dengan tujuan memperbaiki kualitas pelayanan publik dinamakan e-government (Indrajit, 2002). Universitas Brawijaya sendiri, untuk mewadahi aspirasi, keluhan, komentar, saran dan kritik untuk menunjang perbaikan UB kedepan, telah menyiapkan sebuah sistem yang bernama e-complaint yang telah diluncurkan mulai Tahun 2011. Sistem ini bertujuan untuk memberikan wadah aspirasi, keluhan, komentar, saran dan kritik baik dari masyarakat luar maupun dari dalam UB sendiri, baik tenaga pendidik, kependidikan maupun mahasiswa agar lebih mudah untuk mengkasesnya. Kemudahan serta keterbukaan informasi inilah yang kemudian harus ditingkatkan oleh Universitas Brawijaya dalam rangka menunjang pelayanan publik yang diberikan.

Berdasarkan implementasi e-complaint dan perkembangan keluhan para pengguna layanan di Universitas Brawijaya, yaitu perkembangan jumlah keluhan total di Tahun 473 keluhan di Tahun 2016 menjadi 661 keluhan di Tahun 2017, penulis tertarik untuk melakukan penelitian di Pusat Informasi, Dokumentasi dan Keluhan Universitas Brawijaya dengan menekankan pengkajian pada efektivitas pelaksanaan e-complaint. Analisis yang dilakukan penulis dalam penelitian ini meliputi pelaksanaan $e$ complaint beserta kendala-kendala yang dihadapi dalam pelaksanaan tersebut. Oleh karena itu penelitian ini bertujuan untuk menganalisa efektivitas pelaksanaan $e$ complaint serta mengetahui dan menganalisa kendalakendala yang dihadapi dalam pelaksanaan e-complaint di PIDK Universitas Brawijaya tersebut. Sehingga dapat memberikan kontribusi terhadap perbaikan proses, prosedur dan penyelesaian kendala yang dihadapi dalam penanganan $e$-complaint di PIDK UB.

\section{Teori}

\section{$2.1 \quad$ E-Complaint (Keluhan Elektronis)}

Menurut Peraturan Presiden Nomor 76 Tahun 2013, pengaduan adalah penyampaian keluhan yang disampaikan oleh pengadu kepada pengelola pengaduan pelayanan publik atas pelayanan publik pelaksana yang tidak/ belum sesuai dengan standar pelayanan, atau pengabaian kewajiban dan/atau pelanggaran larangan oleh penyelenggara layanan.

Secara definisi keluhan diartikan sebagai satu pernyataan atau ungkapan rasa kurang puas terhadap satu produk atau layanan jasa, baik secara lisan maupun tertulis, dari penyampai keluhan baik internal maupun eksternal. Atau sebuah ungkapan ketidakpuasan antara harapan dengan fakta terhadap apa yang diterima dalam bentuk produk maupun layanan jasa.

Hirschman (1970:39) menyatakan ada tiga bentuk tanggapan yang dapat dilakukan masyarakat atas pelayanan yang mengecewakan, yaitu:

a) Exit, dilakukan saat masyarakat yang tidak puas pada pelayanan dengan cara mencari alternatif pelayanan dari organisasi / lembaga lain;

b) Voice, dilakukan dengan cara keluhan pada birokrasi layanan; dan

c) Loyalty, merupakan bentuk kesetiaan masyarakat terhadap birokrasi yang melakukan pelayanan, 
meskipun mempunyai pilihan untuk melakukan exit, namun lebih memilih voice untuk mengungkapkan kekecewaan kemudian tetap loyal pada organisasi.

Sedangkan keluhan secara elektronis adalah keluhan yang disampaikan kepada pemberi layanan atas ketidakpuasan atau hal lainnya yang berkaitan dengan layanan secara elektonis melalui media internet. Hal ini dilakukan untuk memudahkan dalam proses tata kelola pemerintahan dan meningkatkann proses layanan kepada pengguna layanan. Untuk Universitas Brawijaya sendiri laman e-complaint yang bisa diakses adalah melalui laman https://e-complaint.ub.ac.id/.

\subsection{Pelayanan Publik}

Pelayanan Publik menurut Undang-undang Nomor 25 Tahun 2009 Tentang Pelayanan Publik didefinisikan sebagai kegiatan pelaksanaan kebutuhan pelayanan yang disesuaikan dengan peraturan undang-undang bagi setiap warga Negara dan penduduk atas barang, jasa, dan atau pelayanan administratif yang disediakan oleh penyelenggara pelayanan publik.

\subsection{Efektivitas Pelayanan Publik}

Kata efektif berarti terjadinya suatu hasil atau implikasi yang dikehendaki dalam suatu tindakan. Kata efektif berarti berhasil, sesuai, ampuh (Wojowisoto, 1980). Jadi efektivitas adalah suatu keadaan yang berarti tentang terjadinya suatu efek atau akibat yang dikehendaki. Jika seseorang melakukan perbuatan dengan tujuan tertentu atau mempunyai tujuan sebagaimana yang diinginkan, maka orang tersebut dikatakan efektif (Westra et al, 1989:149). Handoko (1993:7) berpendapat efektifitas adalah kesanggupan untuk mencapai tujuan yang tepat atau alat yang digunakan untuk mencapai tujuan yang telah ditetapkan.

Gie (1988:34) berpendapat bahwa:

Efektivitas adalah keadaan yang berarti terjadinya suatu implikasi atau akibat yang diinginkan, maka perbuatan itu dianggap efektif kalau menimbulkan akibat sebagaimana yang diinginkan.

Adapun Yamit (2003:14) mendefinisikan efektivitas sebagai:

Tolok ukur yang memberikan penggambaran seberapa jauh tujuan tersebut tercapai, baik secara mutu ataupun waktu yang berfokus pada output yang dihasilkan.

Sementara itu, Steers (1980:87) mengemukakan bahwa: Efektivitas adalah usaha suatu rancangan sebagai suatu kesatuan sistem dengan sumber daya dan sarana yang ditentukan untuk memenuhi tujuan dan sasaran tanpa melumpuhkan sumber daya itu serta tanpa memberi pengaruh yang tidak wajar terhadap pelaksanaannya.
Efektivitas juga merupakan alat ukur dalam arti tercapainya tujuan yang telah ditentukan sebelumnya merupakan sebuah pengukuran dimana suatu target telah tercapai sesuai dengan apa yang telah diprogram. Menurut Sedarmayanti (2009:60) ukuran efektivitas untuk suatu organisasi atau lembaga adalah:

a) Masukan;

b) Proses produksi;

c) Hasil; dan

d) Produktivitas.

Sharma (dalam Tangkilisan, 2005:64) memberikan kriteria efektivitas organisasi yang menyangkut faktor internal dan eksternal organisasi antara lain sebagai berikut:

a) Produktivitas organisasi atau output;

b) Efektivitas organisasi berhasil menyesuaikan diri dengan perubahan-perubahan didalam dan diluar organisasi; dan

c) Tidak terjadi ketegangan dalam organisasi atau hambatan-hambatan konflik antar bagian-bagian organisasi.

Salah satu jalan untuk menelaah efektivitas ini ialah dengan cara memperhatikan secara bersamaan tiga buah gagasan yang saling berkorelasi, diantaranya adalah: (a) mengerti mengenai optimisme sasaran; (b) pandangan sistematika; dan (c) titik fokus pada skema perilaku manusia dalam struktur lembaga.

\section{Metode Penelitian}

Penelitian ini menggunakan pendekatan kualitatif untuk menelaah kondisi obyek secara alamiah dimana peneliti sebagai instrumen utama, teknik pengumpulan data dilakukan secara gabungan, analisis data bersifat induktif dan hasil penelitian kualitatif lebih menekankan makna dari pada generalisasi. Pendekatan tersebut dipilih karena penelitian ini ingin menjabarkan data, fakta, dan kondisi atau kerentanan yang ada di obyek penelitian, serta melakukan analisa dan rekaan tentang apa yang harus dilakukan untuk mencapai keadaan yang diinginkan di masa mendatang.

Metode yang digunakan dalam penelitian ini adalah metode deskriptif yang berusaha menggambarkan dan menginterprestasi obyek sesuai dengan fakta yang ada. Dalam penelitian ini, penulis mendeskripsikan fakta terkait efektivitas serta kendala dalam pelaksanaan $e$ complaint pada Universitas Brawijaya Malang. Berdasarkan pendeskripsian tersebut diharapkan ditemukan gambaran dan solusi yang sekiranya tepat untuk perbaikan dan peningkatan pelayanan publik di Universitas Brawijaya Malang.

Keseluruhan informasi yang digunakan dalam penelitian ini dihimpun dari para informan. Dalam menentukan informan digunakan teknik probability 
sampling dan non probability sampling. Metode probability sampling menggunakan simple random sampling dilakukan kepada informan mahasiswa untuk membantu memperkaya hasil penelitian. Wawancara dilakukan terhadap kurang lebih 50 orang mahasiswa. Untuk metode non probability sampling menggunakan metode purposive sampling dilakukan kepada orangorang atau pejabat yang mendalami e-complaint di PIDK UB, yaitu terdapat tiga orang yang bertugas untuk menangani $e$-complaint.

Sesuai dengan pendekatan yang digunakan, maka digunakan tiga teknik pengumpulan data, yaitu: wawancara mendalam, dokumentasi dan observasi. Pemeriksaan keabsahan informasi yang digunakan, yaitu dengan teknik triangulasi data. Wawancara mendalam dilakukan dengan melakukan wawancara terhadap informan mahasiswa dan dari pihak PIDK UB. Wawancara dilakukan hingga mendapatkan data jenuh atau jawaban yang bisa mewakili hasil penelitian penulis. Dokumentasi dilakukan dengan meneliti dokumen dan peraturan yang sesuai dengan penelitian penulis. Observasi dilakukan dengan memperhatikan proses kerja atau prosedur layanan PIDK UB yang dilakukan selama rentang waktu kurang lebih 20 hari pada bulan Maret Tahun 2018.

Proses analisis data dilakukan oleh peneliti melalui tahapan-tahapan antara lain: pengumpulan data, reduksi data, display data, serta penyimpulan dan verifikasi. Tahapan dalam pengumpulan data yaitu: a) pengecekan terhadap semua data yang diambil dilapangan; b) pengorganisasian/ pengelompokan data untuk mempermudah pengecekan data; dan c) coding pada data yang sudah ada untuk memudahkan pengidentifikasian data.

\section{Hasil Penelitian Dan Pembahasan}

\subsection{Pelaksanaan E-complaint di Pusat Informasi, Dokumentasi, dan Keluhan Universitas Brawijaya}

E-complaint ini dapat dilakukan oleh tiap orang yang telah dan akan mendapatkan layanan yang diberikan oleh Universitas Brawijaya, meliputi antara lain; orang tua mahasiswa, mahasiswa, dosen, pegawai, serta pihak lain yang berhubungan dengan layanan yang diberikan oleh Universitas Brawijaya. E-complaint ini merupakan salah satu media dalam menunjang pelayanan terhadap pengguna layanan Universitas Brawijaya. Bentuk layanan penanganan keluhan yang disediakan oleh Universitas Brawijaya yang disebut dengan e-complaint dapat secara mudah diakses oleh berbagai kalangan baik itu dari lingkungan internal UB maupun pihak eksternal dilaman http://ecomplaint.ub.ac.id. Hal ini seperti yang terungkap dalam prosesi wawancara dengan staf penanganan keluhan di PIDK UB, Bapak Ubayd berikut:

"E-complaint ini kan aslinya adalah bentuk kekinian dari cara untuk menyampaikan kritik dan saran orang, entah itu mhasiswa atau dosen atau bahkan orang luar terhadap pelayanan di UB. yaahh, kalau dulunya pakai kertas trus dimasukkan ke kotak saran, sekarang bisa disampaikan lewat online begitu bedanya" (Selasa, 13 Februari 2018: $12.18 \mathrm{WIB})$.

Dari laman tersebut dapat diketahui tujuan dari diterapkannya e-complaint ini adalah supaya pengguna jasa layanan dapat menyampaikan keluhan, saran dan masukan secara online terhadap servis yang disediakan oleh unit kerja di Universitas Brawijaya, baik akademik maupun non akademik. Sedangkan fungsi dari ketersediaan e-complaint tersebut adalah (a) sebagai penjaminan kualitas (quality assurance) pendidikan tinggi dimana prosedur ketetapan dan pemenuhan standar mutu pendidikan secara konsisten dan berkelanjutan dimaksudkan agar konsumen memperoleh kepuasan serta mengciptakan pengembangan yang berkesinambungan (continuous improvement) diperguruan tinggi; (b) sebagai salah satu alat untuk melakukan penilaian dan peringatan awal terhadap celah sistem ataupun anomali pelaksanaan manual mutu guna mencapai visi World Class University; dan (c) sebagai sarana restorasi dan pengembangan dapat dilakukan dengan sesuai dan terus-menerus serta kepuasan konsumen terpenuhi, dikarenakan keluhan konsumen merupakan masukan yang sangat penting dan harus ditindaklanjuti.

Untuk mewujudkan tujuan dan fungsi tersebut maka PDIK perlu melakukan beberapa langkah strategis dalam menerapkan layanan e-complaint dilingkungan UB, yaitu dengan cara mengelola keluhan pengguna jasa layanan, meneruskan keluhan kepada unit yang bertanggung jawab dan menjawab keluhan berdasar masukan dari unit yang bertanggung jawab, yang mana hal ini sesuai dengan Peraturan Presiden Nomor 76 Tahun 2013 tentang Pengelolaan Pengaduan Pelayanan Publik Pasal 2 dan 3; dan Lampiran Keputusan Rektor Universitas Brawijaya Nomor 291/SK/2013 tentang Penerapan Standar Pelayanan pada Jenis Pelayanan $e$ complaint Universitas Brawijaya. Pengguna jasa layanan menyampaikan keluhan bisa dengan berbagai cara, yaitu yang pertama dengan menginput data ke berkas keluhan dan memasukkannya ke drop box; atau cara lainnya, yaitu dengan mengirim keluhan melalui $e$ mail ke alamat e-mail keluhan pengguna jasa layanan.

Keluhan yang disampaikan oleh pengguna layanan harus mencantumkan: (a) subyek keluhan; (b) isian tentang keluhan dan data tentang kejadian layanan yang dikeluhkan serta pihak yang memberikan layanan; (c) 
usulan perbaikan; (d) identitas pengguna jasa layanan; dan (e) alamat e-mail. Kriteria-kriteria tersebut yang kemudian menentukan apakah keluhan yang masuk ke PIDK layak untuk direspon dan ditindaklanjuti atau tidak. Keluhan dari pengguna layanan yang masuk ke PIDK UB masuk dalam kriteria tidak layak untuk direspon dan ditindak lanjuti jika:

a) Keluhan tersebut tidak jelas; dan

b) Keluhan tersebut tidak menampilkan data dan identitas pengguna, yang meliputi: nama lengkap, nomor identitas, e-mail, dan nomor handphone.

\subsection{Prosedur Layanan E-Complaint PIDK UB}

Awal mula pengguna jasa layanan menyampaikan keluhannya diberikan dua pilihan penyampaian yaitu dengan mengakases laman e-complaint di http://ecomplaint.ub.ac.id atau dapat menyampikan langsung keluhannya melalui drop box keluhan PIDK UB yang berlokasi digedung Rektorat UB. Terdapat beberapa hal yang menjadi tolak ukur dalam menerapkan $e$-complaint sebagai upaya untuk memberikan pelayanan kepada pengguna dilingkungan Universitas Brawijaya. Diantaranya perihal penyampaian keluhan oleh pengguna, penanganan keluhan, penyampaian keluhan kepada unit, penindaklanjutan keluhan, serta penyelesaian keluhan.

Jika perlu, keterbatasan identitas pengguna jasa layanan yang mengeluh dapat disembunyikan oleh PIDK. Petugas atau operator bagian keluhan di PIDK setiap harinya akan mengecek dan mendata serta menghimpun keluhan di e-complaint yang dikelola oleh PIDK untuk kemudian petugas tersebut menyerahkan hasil kompilasi keluhan pengguna jasa layanan kepada Pejabat Pengelola Informasi dan Dokumentasi (PPID). PPID ini yang nantinya akan menguji dan mengkelompokkan keluhan yang pantas dan komperehensif untuk ditindaklanjuti, dan keluhan yang tidak pantas serta tidak komperehensif ditindaklanjuti, serta memberitahu kepada pengguna jasa layanan melalui e-mail, bahwa komplen telah sampai dan segera ditanggapi. Penyortiran kriteria kelayakan keluhan yang disampaikan mengacu pada penetapan syarat keluhan yang telah ditetapkan oleh PID melalui SK Rektor. Kriteria tersebut terungkap dari hasil wawancara dengan staf Keluhan di PIDK, Bapak Ubayd:

“.. nggak semua keluhan yang masuk ke kita ditindaklanjuti ya, kalo kita nilai tidak layak ya misalanya seperti identitas tidak diisi dengan jelas terutama nama, kartu identitasnya bisa nomor KTP bisa NIM dan alamat email, karena kita kan nanti konfirmasinya juga via email. Jadi ya biar tidak seperti surat kaleng begitu, bisa dipertanggungjawabkanlah" (Selasa, 13 Februari 2018: 12.18 WIB).
Kemudian PIDK setiap hari menyampaikan keluhan kepada unit-unit terkait dilingkungan UB. Selanjutnya pejabat ataupun Kepala Unit atau fakultas terkait melakukan klarifikasi tertulis dengan format borang yang ada (dengan menggunakan aplikasi $e$ complaint) tentang keluhan tersebut dan menyampaikannya kepada PPID melalui admin yang ada diunit atau fakultas, paling lambat empat hari kerja. Meskipun pada kenyataannya semua tugas tersebut dirangkap oleh petugas pengelola keluhan. Bila perlu restorasi secara fisik, dalam tanggapan tersebut dicantumkan waktu pengerjaannya. PPID kemudian mengevaluasi hasil perbaikan, dan jika diperlukan melakukan visitasi ke unit kerja yang dikeluhkan, serta menyampaikan hasil perbaikan keluhan dari masingmasing Kepala Unit dan fakultas kepada PIDK. Hasil akhirnya PIDK memberitahukan produk restorasi keluhan kepada pengguna layanan maksimal dua hari kerja.

\subsection{Manfaat Layanan E-Complaint PIDK UB}

E-complaint memudahkan pengguna layanan untuk terintegrasi dengan unit-unit lain dilingkungan UB. Dikembangkannya e-complaint untuk mengakomodir pelayanan keluhan dilingkungan UB telah membentuk suatu daerah pelayanan yang secara segera dan efektif mengatasi berbagai masalah yang dihadapi para pengguna layanan dalam lingkup layanan publik sesuai dengan pengubahan global dan kecenderungan yang berjalan. E-complaint dapat membentuk keterbukaan antara pihak UB sebagai pelayan publik dengan para pengguna layanan sehingga menambah keterbukaan, kendali, dan akuntabiliti pelaksanaan layanan publik. Selain itu, juga memperkecil cukup banyak biaya administrasi secara total, dan hubungan yang dikeluarkan untuk keperluan aktivitas sehari-hari. Dalam hal ini konteks keluhan tidak hanya diketahui oleh pengguna layanan yang melakukan keluhan dan PIDK UB selaku media perantara penerima keluhan. Karena segala bentuk keluhan yang disampaikan dapat dilihat secara langsung grafiknya di website PIDK UB.

Disisi lain e-complaint ini dapat memotong jalur birokrasi yang harus dilewati dalam menyampaikan keluhannya ke unit-unit dilingkungan UB. Dalam pelaksanaannya e-complaint berpedoman pada Keputusan Rektor Universitas Brawijaya Nomor: 291/SK/2013 tentang Penetapan Standar Pelayanan Pada Jenis Pelayanan E-complaint Universitas Brawijaya. Dalam surat keputusan itu telah diatur bahwa maksimal empat hari kerja dihitung sejak keluhan diterima, pelaksana penanganan keluhan harus melaksanakan pemilhan dan tanggapan serta maksimal lima hari kerja dihitung sejak keluhan diterima, keluaran tanggapan keluhan harus sudah diumumkan kepada pengeluh. 


\subsection{Perkembangan Keluhan dalam E-Complaint PIDK UB}

Bentuk keluhan secara tertulis dapat dilakukan langsung ke bagian keluhan PIDK UB. Overall fasilitas yang disiapkan akan tetap dimasukkan dan terkoneksi ke e-complaint, jadi pengguna layanan yang tidak memakai fasilitas elektronik tetap bisa memberikan keluhannya secara langsung. Berdasarkan data PDIK UB, keluhan yang masuk melalui e-complaint sebanyak 661 keluhan di Tahun 2017. Dari klasifikasi jenis keluhan tersebut, keluhan terhadap pembiayaan, sarana dan prasarana, sistem informasi menempati urutan tertinggi yaitu 39,6 $\%$ dari keseluruhan keluhan yang masuk serta beberapa keluhan lain

Selain memudahkan untuk mengakomodir keluhan yang ada, adanya e-complaint memudahkan untuk mengetahui unit dan fakultas manakah yang paling banyak mendapat keluhan pelanggan serta masalah apa yang paling sering dikeluhkan oleh pengguna layanan. Dalam hal ini juga dapat dilihat seberapa jauh kesiapan dan tanggapan unit ataupun fakultas dalam merespon keluhan yang diberikan oleh pengguna layanan. Unit yang paling tinggi mendapatkan keluhan dari pengguna layanan ialah FILKOM (Fakultas Ilmu Komputer) sebanyak 306 keluhan (meliputi 46 keluhan yang masih dalam tahapan diproses, 259 keluhan dengan status telah selesai dan 1 keluhan tidak layak untuk diteruskan). Sedangkan dari unit yang paling sering mendapatkan keluhan bagian TIK dengan jumlah keluhan sebanyak 55 keluhan (meliputi 1 keluahan dalam proses dan 54 keluhan lainnya telah terselesaikan).

Tabel 1 Jumlah Keluhan Berdasarkan Lingkup Keluhan Tahun 2013-2017

\begin{tabular}{|c|l|c|c|c|c|c|}
\hline No & Lingkup Keluhan & 2013 & 2014 & 2015 & 2016 & 2017 \\
\hline 1 & Visi, Misi, Tujuan dan Sasaran, Serta Strategi Pencapaian & 135 & 87 & 99 & 106 & 147 \\
\hline & Tata Pamong, Kepemimpinan, Sistem Pengelolaan dan & & & & & \\
2 & Penjaminan Mutu & 71 & 19 & 63 & 34 & 40 \\
\hline 3 & Mahasiswa dan Lulusan & 45 & 38 & 61 & 94 & 35 \\
\hline 4 & Sumberdaya Manusia & 17 & 19 & 28 & 30 & 40 \\
\hline 5 & Kurikulum, Pembelajaran, dan Suasana Akademik & 62 & 65 & 70 & 41 & 68 \\
\hline 6 & Pembiayaan, Sarana dan Prasarana, Sistem Informasi & 218 & 86 & 115 & 106 & 261 \\
\hline 7 & Penelitian, Pengabdian Kepada Masyarakat, Kerjasama & 6 & 2 & 7 & 11 & 9 \\
\hline 8 & Layanan Teknologi Informasi & & 45 & 35 & 47 & 56 \\
\hline 9 & Keluhan Tidak Layak Jumlah & & & 11 & 4 & 5 \\
\hline & 554 & 361 & 489 & 473 & 661 \\
\hline
\end{tabular}

Sumber: Hasil analisis, 2018

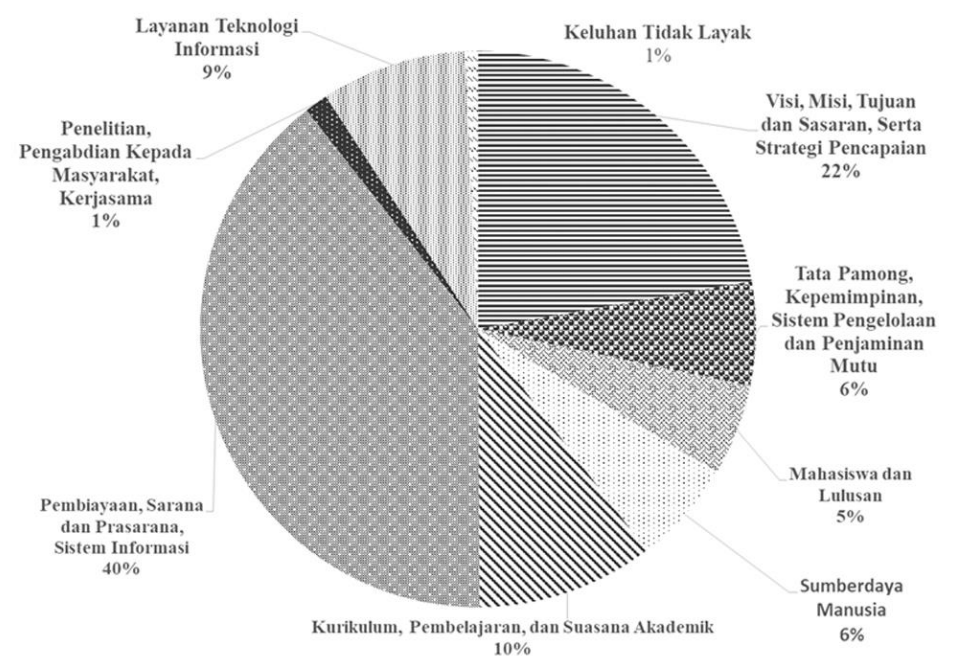
Keterangan :
Keluhan terbanyak di lingkup pembiayaan, sarana dan prasarana sistem informasi di karenakan banyak keluhan, saran dan masukan dari pengguna jasa untuk perbaikan seperti keluhan tentang toilet, lampu gazebo, pembiayaan SPP, UKT, sistem informasi seperti SIAM, dan lain-lain.
Setelah itu keluhan terbanyak juga berada di lingkup keluhan visi, misi, tujuan dan sasaran, serta strategi pencapaian. Setelah kami lihat di database, keluhan yang masuk mengenai pelaksanaan UAS, wisuda, kualitas layanan, homebase dosen, tukang parkir, peningkatan kualitas security, dan lain-lain.
$\mathrm{Nb}$ : Masih banyak pengguna E-Complaint yang masih asal dalam memilih lingkup keluhan saat menggunakan sistem E-Complaint ini. Sehingga masih banyak keluhan yang salah ruang lingkup pilihannya, tapi tetap kita tindaklanjuti.

Gambar 1 Diagram Lingkup Keluhan Tahun 2017

Sumber: Hasil analisis, 2018

\subsection{Isu Strategis dalam Lingkup Keluhan E- Complaint PIDK UB}

Persoalan strategis adalah keadaan atau hal yang harus diperhatikan atau diutamakan dalam suatu perencanaan dan perbaikan layanan karena dampaknya yang signifikan bagi kemajuan program dan peningkatan layanan yang dijalankan dimasa mendatang. Adapun isu strategis dalam e-complaint UB tercermin dari konten atau isi keluhan yang disampaikan 
oleh pengguna dan masuk ke PIDK UB. Hal tersebut sangat beragam dan bervariasi setiap tahunnya, bergantung dari isu-isu yang sedang trending pada saat itu. Hal ini terkait dengan lingkup keluhan yang berujung pada penilaian kinerja UB secara keseluruhan maupun unit unit yang bernaung dibawahnya.

Berdasarkan data rekapitulasi keluhan yang disampaikan pada PIDK UB setidaknya terdapat delapan isu strategis yang terangkum dan tertuang ke dalam lingkup keluhan, yaitu sebagai berikut:

a) Kurikulum, pembelajaran, dan suasana akademik;

b) Mahasiswa dan lulusan;

c) Visi, misi, tujuan dan sasaran, serta strategi pencapaian;

d) Sumber daya manusia;

e) Tata pamong, kepimpinan, sistem pengelolaan dan penjaminan mutu;

f) Pembiayaan, sarana dan prasarana, sistem informasi;

g) Layanan teknologi informasi, dan

h) Penelitian, pengabdian kepada masyarakat, kerjasama.

Dari kedelapan lingkup keluhan tersebut yang menunjukkan angka keluhan yang cukup signifikan setiap tahunnya adalah lingkup keluhan pembiayaan, sarana dan prasarana, sistem informasi. Kemudian diikuti oleh lingkup keluhan visi, misi, tujuan dan sasaran, serta strategi pencapai yang mulai menunjukkan angka yang signifikan pula dari Tahun $2013-2017$.

Dalam perkembangannya, pada Tahun 2017 terlihat FILKOM adalah fakultas yang paling banyak menerima keluhan. Hal tersebut bukan dikarenakan jeleknya layanan yang ada difakultas tersebut. Akan tetapi dikarenakan di FILKOM dilakukan sosialisasi secara menyeluruh untuk semua kalangan civitas akademika FILKOM mulai dari dosen, karyawan hingga mahasiswa mengenai penyampaian keluhan melalui sistem $e$ complaint UB. Hal inilah yang memicu peningkatan cukup signifikan terhadap keluhan yang masuk ke laman $e$-complaint PIDK UB yang berasal dari FILKOM.

Isu strategis yang bermuculan seiring dengan upaya perbaikan layanan yang dilakukan oleh UB adalah salah satu perluasan analisa lingkungan eksternal terhadap operasional peningkatan layanan di UB. Apabila dinamika eksternal yang terwakilkan oleh permasalahan dan isu yang muncul dapat diidentifikasi dengan baik maka UB dapat mempertahankan kelangsungan penyelenggaraan layanan untuk peningkatan layanannya di masa mendatang. Unit atau fakultas di lingkungan UB yang tidak mensinkronkan diri secara sama atas isu strategisnya akan mengalami kegagalan dalam meraih keberhasilan penyelenggaraan layanan publik.

\subsection{Efektivitas E-Complaint di Pusat Informasi, Dokumentasi, dan Keluhan Universitas Brawijaya}

Pengukuran efektivitas pada penelitian ini dapat dijabarkan sebagai berikut:

\subsubsection{Input}

Input dalam hal ini adalah keluhan atau masukan atau saran yang masuk ke e-complaint UB. Sebagaimana telah disebutkan sebelumnya bahwa secara formal tujuan dari disediakannya layanan e-complaint ini adalah untuk menampung keluhan, saran dan masukan dari pengguna layanan UB.

Banyaknya keluhan yang masuk ke laman $e$ complaint berdasarkan data statistik keluhan yang masuk ke PIDK UB di Tahun 2017 adalah 661 keluhan. Jumlah ini mengalami kenaikan dari beberapa tahun sebelumnya. Tercatat pada awal Tahun 2014 jumlah keluhan sebanyak 332 keluhan dan meningkat di Tahun 2015 sebesar 446 keluhan serta 473 keluhan di Tahun 2016. Jumlah ini menandakan bahwa semakin banyaknya input berupa keluhan yang masuk ke media e-complaint di PIDK UB.

Keluhan yang masuk ke PIDK UB dari tahun ke tahun mengalami peningkatan. Artinya bahwa tereselenggaranya pelayanan publik di PIDK UB, dimana salah satunya dipengaruhi oleh input berupa keluhan yang masuk, dapat dikatakan berjalan efektif. Hasil wawancara dengan Aruni, mahasiswi FISIP 2014 menyatakan :

“... apa ya? Sebenernya sih untuk masiswa kaya kami ya buat kasih kritik saran gitu lo, pengennya biar segera direspon dan dibenerin apa saran dari kami" (Kamis, 22 Februari 2018: 09.34 WIB).

\subsubsection{Proses}

Proses dalam hal ini adalah penanganan dan pengelolaan keluhan dari stakeholder ke pihak yang bertanggung jawab dilingkungan UB. Proses merupakan tahapan mengubah input menjadi output dalam sebuah sistem. Pengukuran efektivitas menggunakan pendekatan sistem menggunakan proses sebagai salah satu tahapan dalam menilai suatu efektivitas. Beberapa aspek yang ditinjau dalam proses adalah bagaimana proses pengolahan atau sortir data oleh PIDK UB yang sudah masuk melalui laman e-complaint. Seperti telah dipaparkan bahwa dalam memberikan keluhan, masukan atau saran terutama melalui laman e-complaint, terdapat beberapa data yang wajib untuk dilengkapi, antara lain adalah sebagai berikut

a) Alamat $e$-mail;

b) Identitas pengguna jasa layanan; 
c) Subyek keluhan;

d) Uraian mengenai keluhan dan informasi mengenai peristiwa layanan yang dikeluhkan serta pihak yang memberikan layanan; dan

e) Usulan solusi;

Keluhan yang sudah disortir menjadi keluhan yang layak, akan diteruskan ke masing-masing PIC PIDK UB yang ada difakultas/ unit. Keluhan yang layak ini diteruskan/ didistribusikan dengan menggunakan laman $e$-complaint yang sudah terintegrasi sesuai dengan user masing-masing. Keluhan yang sudah diterima oleh masing-masing PIC PIDK UB difakultas/ unit terkeluh, akan mencetak keluhan tersebut untuk diteruskan kepada atasan tertinggi, dalam hal ini adalah Dekan/ Kepala Program/ Kepala Unit.

Keluhan yang sudah diterima akan dan harus segera ditanggapi sesuai dengan SOP yang telah disepakati, yaitu empat hari kerja. Namun seringkali kenyataan dilapangan berkata lain. Hal ini tentu akan menyesuaikan dengan lingkup keluhan yang ada. Yang dimaksud adalah apakah memerlukan pekerjaan fisik skala besar atau tidak. Bila memerlukan pekerjaan fisik skala besar, tentu tidak akan bisa segera dilihat tindak lanjut keluhannya. Namun jawaban/ tanggapan atas keluhan bisa dan harus segera dilakukan dengan mencantumkan penjelasan bahwa keluhan yang diberikan memerlukan pekerjaan fisik skala besar dan tidak bisa segera dilakukan dalam waktu dekat. Bila tidak memerlukan pekerjaan fisik, seringkali keluhan bisa segera ditindaklanjuti.

\subsubsection{Output}

Output dalam hal ini adalah jawaban yang diterima oleh stakeholder atas keluhan yang disampaikan. Lalu tanggapan dari fakultas/ unit tersebut apakah sudah sesuai harapan atau tidak. Dari hasil wawancara dengan para stakeholder yang telah menggunakan layanan e-complaint yang dipilih secara acak, maka ditemukan bahwa keluhan yang disampaikan hampir kesemuanya mendapat jawaban sesuai dengan yang diinginkan. Sebagaimana diutarakan oleh Rista (mahasiswi FIB) dalam hasil wawancara berikut:

"pernah ngisi e-complaint dan sudah dapat tanggapan, jadi menurut aku sudah efektif. Cuma yang perlu ditingkatin lagi itu proses nunggu jawabannya. Semoga nantinya bisa lebih cepat dan langsung" (Kamis, 22 Februari 2018: 10.14 WIB).

Beberapa data dukung yang dapat dijadikan dasar untuk menjadi tolak ukur keberhasilan tersebut adalah diraihnya beberapa penghargaan oleh PIDK UB dalam hal keterbukaan informasi publik, serta angka IKM (Indek Kepuasan Masyarakat) yang menunjukkan angka positif dalam mencapai keberhasilan pelayanan. Output lainnya adalah dengan adanya Laporan Penanganan Keluhan Pengguna Jasa Layanan Per Tahun,
Rekapitulasi Keluhan Per Unit jika diminta oleh unit yang bersangkutan dan sebagai bahan untuk Laporan Rektor.

\subsubsection{Produktivitas}

Produktivitas dalam hal ini adalah bagaimana keluhan yang sudah ditanggapi oleh pihak fakultas atau bagian atau unit dapat memberikan dampak positif terhadap layanan yang berjalan dilingkungan Universitas Brawijaya. Dari aspek produktifitas $e$ complaint terdapat hal-hal yang ditekankan yaitu: dari segi aspek pendukung (support), aspek kapasitas (capacity) dan aspek nilai yang didapat (value). Hasil wawancara dengan ketua PIDK, Bapak Tjahjanulin:

"Salah satu komponen yang diperhitungkan dan selalu ada disetiap lembaga ya e-complaint. Karna keluhan itu adalah tanda perhatian kita terhadap stakeholder. Di Tahun 2009 ada pelayanan prima dan keterbukaan informasi yang memberi sporting bagi UB untuk meningkatkan layannya. Kenapa pelayanan kurang padahal UB sudah berkomitmen penuh dan sudah melakukan berbagai cara dan juga secara anggaran sudah ada itu. Meskipun masih butuh pengembangan dan itu tidak murah ya" (Rabu, 21 Februari 2018: 15.11 WIB).

Adapun yang dimaksud dengan aspek produktifitas e-complaint adalah sebagai berikut:

a) Pertama dari segi pendukung (support) yang terbagi dari: sumber daya finansial, komitmen, dan regulasi. Dilihat dari support secara anggaran, sudah ada alokasi khusus yang ditujukan untuk pengelolaan $e$ complaint. Sedangkan untuk commitment, sejauh ini komitmen UB dalam mensupport perluasan dan memanfaatkan $e$-complaint dalam menampung suara dan keluhan dari pengguna layanan sudah cukup baik;

b) Aspek kedua, yaitu kapasitas yang terbagi dari SDM dan ketersediaan infrastruktur yang memadai. SDM ini berhubungan dengan jumlah dan kompetensi pegawai. Dilihat dari jumlah pegawai yang ada, pegawai yang terdapat saat ini masuk dalam kategori kurang. Karena jika dihubungkan dengan pelayanan dengan berbasis pada media teknologi informasi seharusnya jumlah pegawai dalam lingkup kecil yang sudah menggunakan dukungan media elektronik untuk memotong alur birokrasi, akan tetapi alangkah lebih baiknya jika staf yang disediakan lebih terspesifikasi antara petugas pengelola keluhan dengan petugas pengelola IKM. Sedangkan persoalan keberadaan infrastruktur TI yang mencukupi untuk saat ini dapat dibilang bahwa dari segi peralatan penunjang pelaksanaan $e$-complaint di UB sudah cukup baik. Karena laman e-complaint ini bisa secara mudah diakses dan tidak butuh waktu yang lama untuk mengaksesnya; dan 
c) Ketiga, yaitu dari aspek nilai. Berbeda dengan kedua aspek diatas yang dilihat dari bagian instansi, yaitu UB sebagai pihak pemberi jasa dan layanan (supply side), aspek manfaat atau nilai akan melihat dari sudut service user sebagai pihak yang berkebutuhan dalam mengakses informasi atau servis yang disediakan oleh UB. Adanya e-complaint memberikan efek positif jadi pengguna layanan tidak perlu bingung lagi untuk menyampaikan keluhannya dan tidak harus datang secara langsung ke unit terkait karena bisa diakses dari mana saja selama terdapat koneksi internet.

\subsection{Kendala yang dihadapi dalam Pelaksanaan E- Complaint di Pusat Informasi, Dokumentasi, dan Keluhan Universitas Brawijaya}

Beberapa kendala yang dihadapi dalam pelaksanaan e-complaint yang ditemukan dalam penelitian ini, antara lain adalah:

a) Kendala Internal

- Rangkaian penyaluran keluhan dari operator $e$ complaint ke bagian-bagian kecil bidang di tiaptiap unit yang masih dijalankan secara manual;

- Belum dimanfaatkannya dengan maksimal aplikasi e-complaint. Selain pembuatan sistem atau aplikasi e-complaint, setiap tahunnya juga dibutuhkan biaya pemeliharaan untuk perawatan yang meliputi perluasan program, sosialisasi dan pengembangan sistem;

- Jaringan internet yang terkadang mengalami gangguan dalam pengelolaan keluhan $e$ complaint, tersedianya saluran internet yang baik merupakan salah satu komponen utama dan sangat penting;

- Kesiapan sumber daya manusia dalam menjalankan pengelolaan keluhan e-complaint, baik dari segi kualitas dan kuantitas; dan

- Tidak adanya tim monitoring dan evaluator yang mengendalikan tindaklanjut pengelolaan pengaduan.

b) Kendala Eksternal

- Mindset dan budaya dari pengguna layanan yang mengkesampingkan prntingnya sebuah kritik untuk perbaikan; dan

- Respon Balik (feedback) dari pengguna layanan yang belum baik dalam pengelolaan keluhan.

\section{Kesimpulan}

Berdasarkan uraian mengenai permasalahan yang telah dijelaskan diatas maka dapat disimpulkan bahwa:

a) Pertama, pelaksanaan e-complaint di PIDK UB telah berjalan sesuai tujuan dan fungsinya melalui standar layanan dan serangkaian prosedur yang ditetapkan serta telah memberikan manfaat bagi pengguna layanan yang terlihat dari beberapa penghargaan yang berhasil diraih oleh PIDK UB;

b) Kedua, penerapan e-complaint di PIDK UB berjalan cukup efektif dalam upayanya meningkatkan pelayanan publik dalam hal input, output dan juga produktivitas. Sedangkan dalam hal proses, masih belum dapat dikatakan efektif karena masih menemuai banyak kendala yang cukup signifikan; dan

c) Ketiga, kendala yang dihadapi penyedia pelayanan dan juga pengguna layanan e-complaint di PIDK UB terbagi menjadi dua, yaitu kendala internal dan kendala eksternal. Kendala internal, yaitu: Alur penyaluran keluhan dari admin e-complaint ke subsub bidang di masing-masing unit masih dilakukan secara manual; biaya maintenance untuk perawatan, sosialisasi dan pengembangan sistem cukup besar; jaringan internet; kurangnya kesiapan sumber daya manusia; keterbatasan sumber daya manusia. Sedangkan kendala eksternal, yaitu: mindset dan budaya trekait keterbukaan informasi sehingga mengkesampingkan pentingnya sebuah kritik untuk perbaikan (pengguna maupun pemberi layanan); serta tidak adanya umpan balik (feedback) dari pengguna layanan.

\section{Daftar Pustaka}

Gie, Liang The. (1988). Unsur-Unsur Administrasi. Erlangga. Jakarta

Handoko, T. Hani. (1993). Manajemen Personalia dan SDM. Yogyakarta: BPFE.

Hirschman, Albert O. (1970). Exit, Voice, and Loyalty: Responses to Decline in Firms, Organizations, and States. Cambridge. Harvard University Press.

Indrajit, D. R. (2002). Electronic Government : Strategi Pembangunan Dan Pengembangan Sistem Pelayanan Publik Berbasis Teknologi Digital. Yogyakarta: Andi.

Keputusan Rektor Universitas Brawijaya Nomor: 291/SK/2013 tentang Penetapan Standar Pelayanan Pada Jenis Pelayanan E-complaint Universitas Brawijaya

Peraturan Presiden Nomor 76 Tahun 2013 tentang Pengelolaan Pengaduan Pelayanan Publik.

Sedarmayanti. (2009). Sumber Daya Manusia dan Produktivitas Kerja. Bandung: Mandar Maju.

Steers, Richard M. (1980). Efektivitas Organisasi (Kaidah Perilaku). Jakarta: Erlangga.

Tangkilisan, Nogi Hessel. (2005). Manajemen Publik. Jakarta: PT. Gramedia Widiasarana Indonesia.

Undang-Undang No 25 Tahun 2009 tentang Pelayanan Publik.

Westra, Pariata., Drs. Sutarto, Ibnu Syamsi., \& Liang Gie The. (1989). Ensiklopeda Administrasi. Pustaka Setia, Bandung. 
Wojowisoto, S. (1980). Manajemen Pelayanan Publik.

Jakarta: Gramedia.

Yamit, Zulian. (2003). Manajemen Produksi dan Operasi, Edisi 2. Yogyakarta: Ekonisia. 